\title{
FIVE BLUES LAKE NATIONAL PARK, BELIZE: A CAUTIONARY MANAGEMENT TALE
}

\author{
Mick DAY'1 AND Bill ReYNOLDS²
}

\begin{abstract}
Karst is inherently dynamic, and this may be manifest in unexpected ways, which may have major implications for management of protected areas, where changes may have major impacts on visitor numbers and revenue streams. In Five Blues Lake National Park, Belize, the principal visitor focus is Five Blues Lake itself. An anomalous feature with characteristics of a karst window or cenote but in the setting of a polje or ponor lake, Five Blues has both surface and underground drainage components. Establishment of the national park proceeded under the impression that the lake was a permanent feature, but over July 20 to 25,2006 , the lake drained rapidly underground. Without the lake, visitor numbers and park revenues declined, and the park was all but abandoned. The lake refilled in 2007, but visitor numbers continue to lag. Management and promotion of hydrologic features within protected areas needs to take such possibilities into account, emphasizing variability and change and avoiding a focus on conditions that may not prevail at any given time.
\end{abstract}

\section{INTRODUCTION}

Designation as protected areas is an important component in the conservation and management of karst landscapes at local, national, regional, and global scales (Day, 1996, 2011; Kueny and Day, 1998, 2002; Watson et al., 1997). Such designation necessitates, however, consideration of impacts on local communities and requires implementation of usage policies that usually must reconcile conservation goals with visitor expectations and economic development priorities (Bundschuh et al., 2007; Day, 2011).

Visitor expectations in protected karst areas often focus on landscape vistas and on specific impressive features, such as caves, valleys, waterfalls, and springs (Bundschuh et al., 2007). These are not, however, fixed and immutable, changing in response to floods, storms, hydrologic variations, and human disturbance. For example, many protected karst areas in Belize were ravaged by Hurricane Richard in 2010, with parks such as St. Herman's Blue Hole and Guanacaste being closed to visitors for several months (Belize Audubon Society, 2010a).

Hydrologic changes, either natural or human-induced, may alter the fundamental character of karst sites, particularly those centered around surface rivers, waterfalls, lakes, stream sinks, underground conduits, and springs. Such features epitomize karst landscapes, and although they represent an interface between the realities of karst science and public perceptions, it is important to recognize and acknowledge their temporal variability in ways that all audiences can appreciate. One particularly dramatic example of this is provided by Five Blues Lake, a protected karst site in Belize whose susceptibility to hydrologic change was essentially unrecognized at the time of its establishment and whose recent history provides a salient lesson for management of similar areas.

\section{Protected Karst in Belize}

Reflecting its colonial history, its low population density, and its post-independence commitment to the conservation of nature and to ecotourism, Belize probably has a higher percentage of its karst under protection than any other country in the world (Day, 1996). Although there is considerable fluidity in precise numbers, currently about $3400 \mathrm{~km}^{2}$, or $68 \%$, of Belize's terrestrial karst, excluding the islands (cayes) of the barrier reef, is designated as some form of protected area, with an additional $900 \mathrm{~km}^{2}(18 \%)$ being incorporated within Special Development Areas, where human activities are supposed to recognize the inherent environmental fragility of the landscape. Karst is present within more than twenty separate terrestrial protected areas and five Special Development Areas (Day, 1996; Escott and Day, 2005). Most of this protection stems not from an explicit recognition of the inherent scientific uniqueness or environmental fragility of the karst, but rather from the intricate association between the karst and other conservation priorities: intact forests with important flora and fauna, hydrologic catchment areas, and significant pre-Hispanic Maya archaeological sites (Day, 1996, 2003a,b). Accordingly, the karst is protected under various categories, including national parks, forest reserves, and archaeological reserves (Day, 1996; Belize Audubon Society, 2010b).

Conservation aside, these protected karst areas also represent significant resources for ecotourism and economic development. Approximately one third of Belize's tourism activity is focused on the karst, with over 50,000

\footnotetext{
${ }^{1}$ Department of Geography, University of Wisconsin-Milwaukee, Milwaukee, Wisconsin 53201, USA. mickday@uwm.edu

${ }^{2}$ Lower Dover Field Station, Unitedville, Belize. lowerdoverbelize@gmail.com
} 


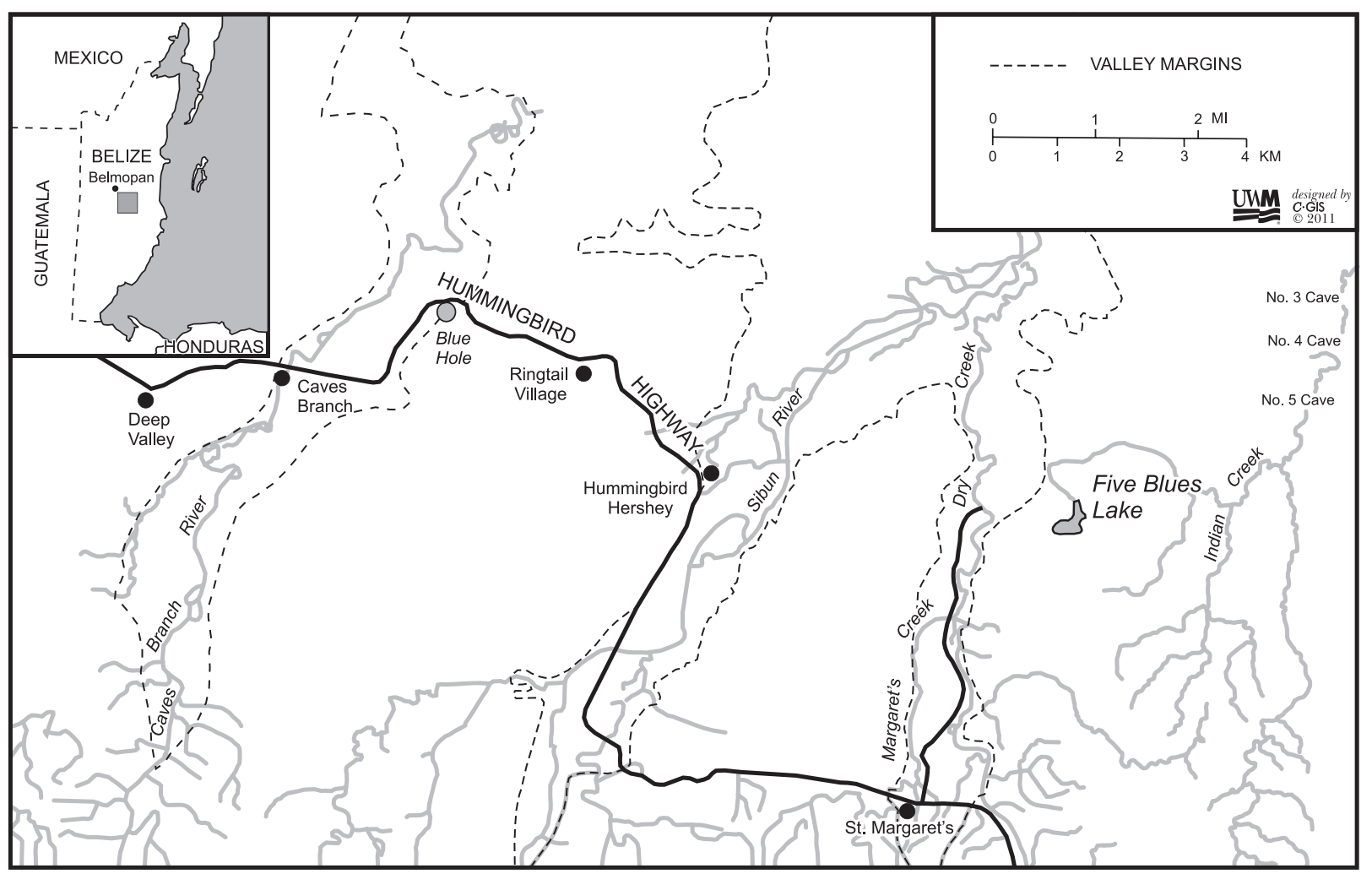

Figure 1. Location of Five Blues Lake.

visitors and an economic income of some US\$15 million annually (Bundschuh et al., 2007).

\section{Five Blues Lake}

Five Blues Lake National Park is located within the Indian Creek valley in the Stann Creek District, bordering the Cayo District of west-central Belize (Fig. 1). It is a component of what has been termed the Hummingbird Karst (Day, 1986, 1987a,b, 1991, 1993; Day and Rosen, 1989), which flanks the Hummingbird Highway and is itself part of the broader Northern Boundary Fault Karst of central Belize (Miller, 1996). The karst consists of a slightly arcuate east-west belt some $60 \mathrm{~km}$ in length and 5 to $10 \mathrm{~km}$ wide and is formed in brecciated Cretaceous-age limestones and dissected into blocks by allogenic rivers draining northward from the adjacent non-karst Maya Mountains (Day, 1986; Miller, 1996). The karst blocks have only intermittent surface drainage and have a rugged topography characterized by dry valleys and karst depressions (Day, 1987c). In contrast, the intervening valleys, some of which are clearly poljes, have alluviated floors and considerable seasonal allogenic surface flow. Surface flow in the Sibun and Caves Branch valleys, with respective upstream catchment areas of some $250 \mathrm{~km}^{2}$ and $90 \mathrm{~km}^{2}$, is perennial, but that in St. Margaret's Creek $\left(20 \mathrm{~km}^{2}\right)$, Dry Creek $\left(40 \mathrm{~km}^{2}\right)$, and Indian Creek $\left(30 \mathrm{~km}^{2}\right)$ is essentially limited to the June-December wet season, and even then, it may be sporadic (Day, 1987b).

Five Blues Lake National park was established in 1991 and enlarged in 1994 to comprise approximately 1640 hectares (4000 acres). Uniquely among Belize's national parks, it is managed by a local NGO, the Association of Friends of Five Blues Lake, with the income being used for park upkeep and management and for local community development (Community Conservation Consultants, 1999; Horwich and Lyon, 1999; Young and Horwich, 2011; Fig. 2). The Belize Forest Department, within the Ministry of Natural Resources and the Environment, has oversight because the park is located within the Sibun Forest Reserve, but does not participate in park management. Access is via an unpaved road leading northward from Mile 32 on the Hummingbird Highway at Santa Martha/St. Margaret's village, the nearest local community, which was established in the mid-1980s and is a center for the local lime-burning industry (Day, 1987b, 2005; White, 1994; Warner, 1996).

Although there are many karst attractions within the park, notably caves, dry valleys, conical hills, and serrated ridges, the principal visitor focus is the 4 ha $(10 \mathrm{ac})$ Five Blues Lake itself. The spectrum of blue shades, reflecting the dry-season water clarity and variable depths, is visually attractive, the lake is important ecologically, and visitors use it for swimming and boating (Fig. 3). Visitor numbers 


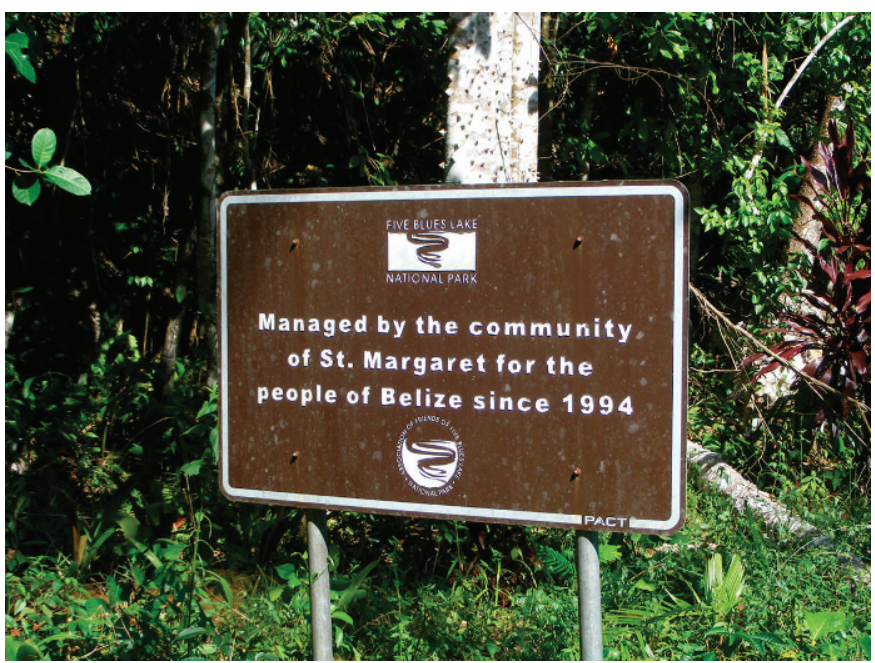

Figure 2. Park sign.

to the park, although never large, increased gradually between 1991 and 2006, from a handful to well over one hundred annually (Community Conservation Consultants, 1999; L. Wengrzyn, personal communication, 1994; M. Perez, personal communication, 2011). Official counts underestimate actual numbers, but the trend of visitor numbers was encouraging, and the contribution to local revenues, although only about Bze $\$ 500$ to 600 (US\$250 to 300) annually, was welcome.

Although there have been no detailed studies of Five Blues Lake, it is clearly an anomalous feature, although in some ways it is analogous to the nearby Blue Hole, a karst window in the St. Herman's Blue Hole National Park adjacent to the Caves Branch valley or polje (Miller, 1977, 1981, 1983, 2006; Day, 1992; Day et al., 1987). Drainage through the Blue Hole involves a trunk conduit running alongside the valley, with cave tributaries beneath both the valley-side ridges and the alluviated polje itself (Miller, 2006). The Caves Branch Cave System includes multiple components, including higher-level breakdown passages, phreatic loops, and collapse-truncated conduits (Miller, 1983, 2006), and "hydraulically restricted cave channels pirate allogenic river water from the polje into the conduit" (Miller, 2006, p. 91). At the same time, surface drainage via the Caves Branch River is maintained by allogenic drainage from the adjacent non-karst Maya Mountains. The surface and subsurface systems are interconnected, with drainage pathways at any particular time reflecting variations in drainage inputs, local system capacities, and hydrologic outputs, and flow eventually into the Sibun River system. Discharge through the $20 \mathrm{~m}$ deep Blue Hole is perennial, but baseflow during the dry season is about $1 \mathrm{~m}^{3} \mathrm{~s}^{-1}$, with wet-season discharges increasing to over $15 \mathrm{~m}^{3} \mathrm{~s}^{-1}$ (Day, 1992).

Despite similarities, the Blue Hole and Five Blues Lake differ in several respects. First, Five Blues Lake occupies a landscape position differing from that of the Blue Hole.

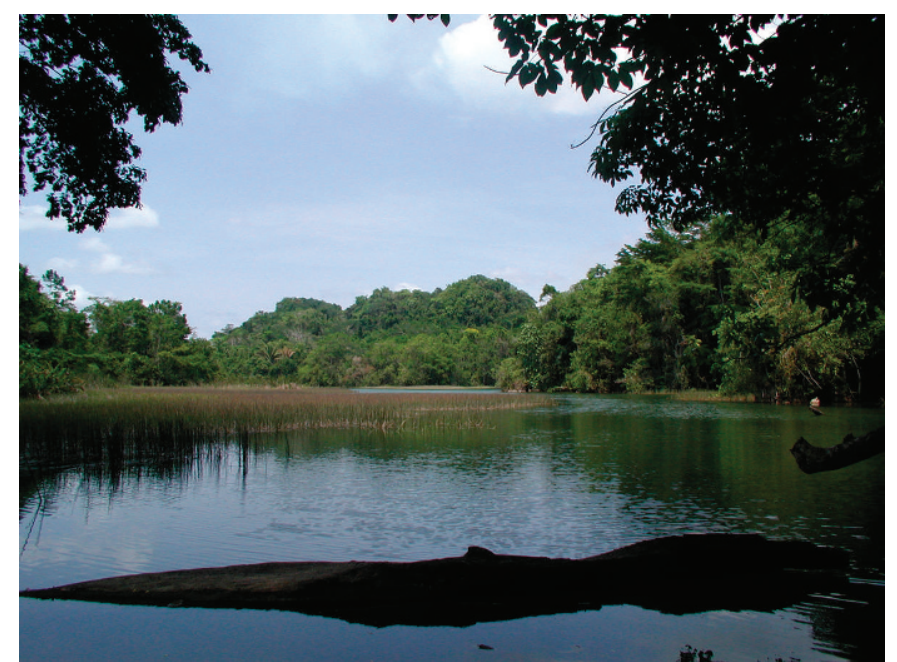

Figure 3. Five Blues Lake before draining.

While the latter is set within the polje border hills, at an elevation of about $60 \mathrm{~m}$ above sea level, the former is located within, although close to the edge of the valley, at an elevation of about $40 \mathrm{~m}$. Second, flow into the Blue Hole is known to be largely from the upstream Petroglyph Cave segment of the Caves Branch system via St. Herman's Cave (Miller, 1983, 2006; Day et al., 1987), but the source of water in Five Blues Lake has not been established, although it is likely from one or more conduits flanking and underlying Indian Creek valley and perhaps the adjacent St. Margaret's/Dry Creek valley. Meerman (2001, 2007) reports shallow subsurface-stream inputs and there appears to be very little surface-stream input. Third, flow out of the Blue Hole is entirely underground via a downstream phreatic loop in the Caves Branch cave system, whereas drainage from Five Blues Lake is usually at least partially via a surface stream (Fig. 4), that flows north, then eastward into Indian Creek, which itself eventually joins the Sibun River some $5 \mathrm{~km}$ south of Churchyard, east of Belmopan. The presence of this surface outlet is perhaps critical to understanding the behavior of Five Blues Lake. Dry season, base-level discharge for the outlet stream was estimated at less than $1 \mathrm{~m}^{3} \mathrm{~s}^{-1}$ in March 1986, with wet season discharge in August 1986 estimated at $3 \mathrm{~m}^{3} \mathrm{~s}^{-1}$ (Day, unpublished). Despite the futility of attempting to correlate surface and underground drainage catchments in karst (Ford and Williams, 2007), it is notable that the apparent surface catchment area upstream from the Blue Hole is about $90 \mathrm{~km}^{2}$, whereas that for Five Blues Lake is less than $10 \mathrm{~km}^{2}$.

Its geomorphological and hydrological characteristics suggest that Five Blues Lake is perhaps best characterized as a compound feature, having many characteristics of a karst window, yet being located within a border polje (Bonacci, 2004a; Ford and Williams, 2007), where it in some respects resembles a polje or ponor lake. Clearly, its 


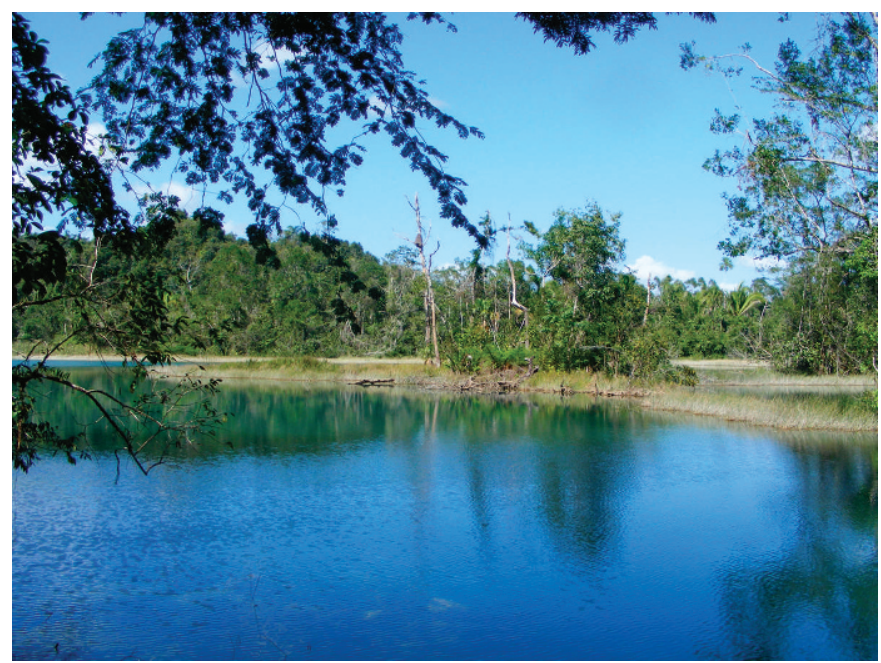

Figure 4. Northeastern part of Five Blues Lake. Surface outlet at right and outlet cave location below water level in right-center.

hydrology involves both surface and underground components, with its level reflecting multiple local inputs and outputs, particularly via sub-alluvial channels and a reversible ponor (sink), or estavelle, (Bonacci, 2004b; Ford and Williams, 2007) that may function as an input or drain, depending on specific hydrological conditions. Drawing an analogy with the Caves Branch polje, Five Blues may exist as a result of the blocking of subsurface drainage from the valley into an adjacent conduit system.

Five Blues Lake is not the only valley or polje lake within the Hummingbird karst; several others within the Caves Branch and Sibun watersheds are depicted on the 1:50,000 topographic sheet (Directorate of Overseas Surveys, 1973), although these have not been studied in detail. These lakes within the karst, including Five Blues and the Blue Hole, are sometimes referred to as cenotes, but this terminology is not really appropriate, because in some ways they are unlike cenotes both morphologically and hydrologically (Beddows, 2004; Day, 2004).

\section{Rapid Lake Drainage in July 2006}

Between 1986 and 2006 water levels in Five Blues Lake appear to have remained relatively stable (Meerman, 2001), although no regular monitoring was conducted and major seasonal fluctuations may have escaped local attention. Minor seasonal fluctuations in lake-surface elevation of less than $1 \mathrm{~m}$ were noted (Day, unpublished), reflecting the seasonal discharge fluctuations estimated above, but these appeared unremarkable. It thus came as a great surprise to all concerned when, over the days July 20 to 25, 2006, the lake essentially disappeared, much of the water draining rapidly underground via what was described as a whirlpool (Meerman, 2001). Fish were stranded, submerged tree trunks were exposed, downstream surface drainage ceased,

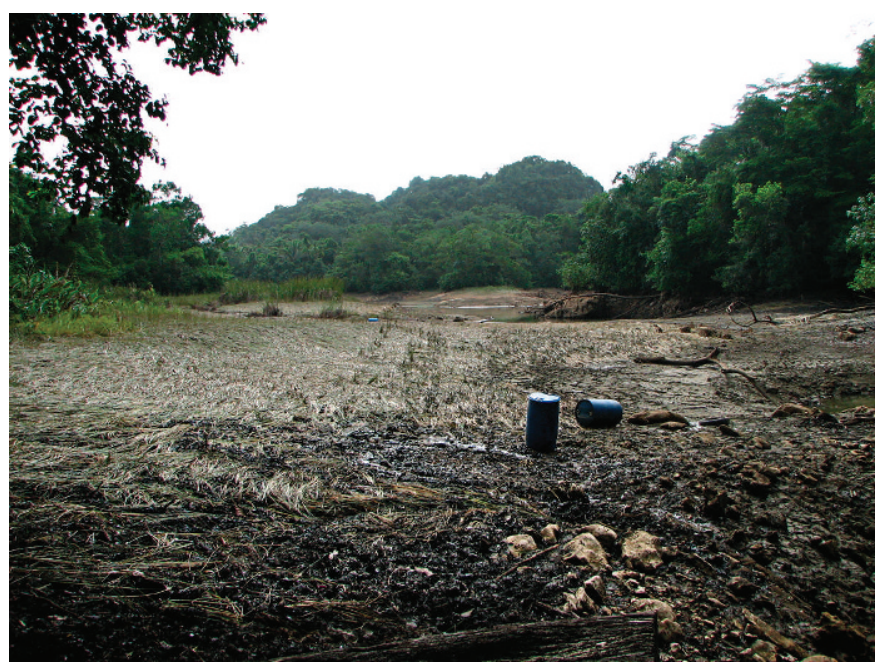

Figure 5. Five Blues Lake after draining.

and the alluviated lake bed was revealed (Fig. 5). Although no detailed measurements were made and water persisted in the deepest parts of the lake's basin, it appeared that the lake surface area decreased by about 75 to $85 \%$, with initial rapid drawdown followed by slower drainage over a threeweek period (M. Perez, personal communication, 2011).

Drainage of the lake revealed that the former depth of much of the lake had been less than $5 \mathrm{~m}$, although with at least five deeper areas (Meerman, 2007; M. Perez, personal communication, 2011). Of these deeper areas, or pits, two were characterized as small, two as larger, and one, adjacent to the surface outlet on the eastern edge of the basin and referred to as the cenote, was apparently up to $45 \mathrm{~m}$ in width and had shear bedrock walls in excess of $70 \mathrm{~m}$ in depth beneath the rim (M. Perez, personal communication, 2011). While these reported dimensions may be questionable (elevation of the Indian Creek valley is only about $40 \mathrm{~m}$ above sea level), clearly the lake developed around at least one deep bedrock pit that had contributed to the deepest blue coloration. Also, significantly, a large cave opening was exposed in the lake bed just north of the cenote, close to the then-abandoned surface stream outlet (Fig. 4). Approximate calculation suggests that the lake volume prior to drainage may have been in excess of $10 \times 10^{6} \mathrm{~m}^{3}$.

\section{Possible Causal Mechanisms}

Heavy rainfall may have played a role in the lake's drainage, in that both June and July 2006 experienced rainfall well above average, which resulted in surface flooding and may have dislodged sediment fills or organic debris in the cave systems. Average monthly rainfall at Belmopan is about $300 \mathrm{~mm}$ in June and $280 \mathrm{~mm}$ in July (Belize National Meteorological Service, 2011a), but rainfall at Hummingbird Hershey, within the Sibun River valley, totalled $432 \mathrm{~mm}$ in June and $672 \mathrm{~mm}$ in July 2006, 
with $881 \mathrm{~mm}$ of rainfall recorded between June 21 and July 21 (Belize National Meteorological Service, 2011b).

Although the precise cause of the lake's rapid drainage remains uncertain, two immediate possibilities arise. First, the drainage may have resulted from a dramatic, nearinstantaneous failure of a plug in the lake-bed cenote that facilitated near-vertical discharge into an underlying cave conduit. Such a process would be unusual; rapid drainage of cenotes has not been reported previously, nor has rapid drainage of polje lakes via collapsing estavelles or ponors been reported previously (A. Kranjc, personal communication, 2010), although such lakes may fill rapidly, and their hydrology is locally complex (Petric and Kogovsek, 2005; Kovacic and Ravbar, 2010). The heavy rainfall of July 2006 may have increased the pressure head in the lake itself, but there is no evidence of a lake-bottom plug either prior to drainage or as a result of sediment erosion before refilling, and the reported depth of the cenote, which puts it well below sea level, suggests that vertical drainage there is unlikely.

Second, the lake may have drained in response to an unblocking event farther downstream within the underlying, perhaps water-filled cave-conduit system downstream of the cave entrance that was exposed at the northern end of the lake, perhaps, again, due to the failure of a conduit obstruction or plug (Meerman, 2007). This latter explanation appears the more probable, given the retention of water within the cenote and exposure of the downstream cave entrance, and it accords generally with the situation in Caves Branch, which includes multiple underground components, including higher-level breakdown passages, phreatic loops, and collapse-truncated conduits (Miller, 1983, 2006).

Thus, Five Blues Lake may indeed be a karst window, analogous to the Blue Hole, although one whose underground outlet is at least partially blocked under normal conditions, leading to water occupying a basin considerably larger than the karst window proper, and with surface overflow via the stream outlet. Thus the local hydrology is complex, involving multiple inlets and outlets, and with considerable vertical differentiation.

Interestingly, Meerman (2001) reported that local residents had previously noted increasingly abrupt fluctuations in the lake and that turbidity appeared to have become less seasonally predictable, perhaps presaging later developments. Also, local residents reported that a new, smaller lake appeared in another part of the park when Five Blues Lake drained, suggesting an underground hydrologic connection. Perhaps most significantly, there were contemporaneous reports in 2006 of unusually high discharges in caves within the Sibun Forest Reserve adjacent to Five Blues Lake (Meerman, 2007), perhaps supporting the unblocking hypothesis outlined above.

\section{Post-Drainage Developments}

With the lake drained, the primary attraction of the national park was gone. Five Blues Lake was never an easy destination to reach without a four-wheel drive vehicle, and word of its fate soon spread via the Internet (Meerman, 2007). Initially, curious visitors, particularly from within Belize itself, visited the site to view the desiccation for themselves, with 250 visitors recorded in 2006 and numerous others undocumented. This rather ironic influx soon dwindled, however, and in subsequent years recorded visitor numbers declined to pre-2000 levels, totalling 70 in 2007, 40 in 2008, and 45 in 2009 (M. Perez, personal communication, 2011). Tourism revenues declined precipitously, from about US\$250 annually, which had been significant for park upkeep, given the essentially subsistence nature of much of the local economy, to less than half that amount, and the park and its access road were neglected until after Hurricane Richard in 2010 (M. Perez, personal communication).

Little was heard from Five Blues Lake in late 2006 and early 2007, but in late June 2007 visitors reported that the lake had refilled. The refilling was a result of groundwater replenishment rather than surface flow, and it occurred very rapidly, like the earlier drainage. After 344 days, during which standing water was more-or-less restricted to the cenote, Five Blues Lake refilled within a single 24 hour period on June 27, 2007 (M. Perez, personal communication, 2011). During the same time the new, smaller lake apparently disappeared, suggesting a subterranean hydrologic connection between the two, where rapid passage constriction, presumably through collapse, had interrupted flow to the smaller lake and caused a rapid backup into the Five Blues Lake basin.

Since 2007, road access has again been improved and facilities have been redeveloped. Visitor numbers, however, continue to lag well behind those pre-drainage (M. Perez, personal communication, 2011), and the park's managers remain understandably concerned both about the cause of the sudden drainage and the future viability of a park centered on an iconic feature which may or may not be present at any given time.

\section{Management Implications And Conclusion}

Although sinkhole collapse, sometimes engulfing small lakes, ponds, sewage lagoons, or swimming pools, is a widely recognized hazard in karst terrain (Waltham et al., 2005), sudden underground drainage of large natural karst lakes appears to be a relatively rare phenomenon, and thus, there are few international parallels to the dramatic disappearance and refilling of Five Blues Lake. Human activities often have profound impacts on karst hydrology (Drew and Hotzl, 1999), but rapid natural fluctuations in tropical karst-lake levels typically involve rain-fed flooding rather than accelerated subterranean draining (e.g., Day, 2007). Relatively rapid historical drainage of karst lakes has been reported in Florida (Kindinger et al., 1999), but polje or ponor lakes typically fill relatively rapidly and drain more slowly, often on a seasonal basis (Bonacci, 
2004a,b), and groundwater fluctuations have impacts on karst lakes such as turloughs (Naughton et al., 2010) and meres (Day and Goudie, 1978).

The establishment and operation of Five Blues Lake National Park proceeded under the impression that the lake was a permanent feature, and the potential for rapid drainage was not appreciated. This may have been a reasonable assumption, although seasonal and other hydrologic variations had perhaps been underestimated. More significantly, anecdotal information suggests that the drainage in 2006 was not the first occasion on which such an event had occurred. In 1981, a since-deceased long-term resident of the Sibun valley, J. Roberts, who had been involved in forestry throughout the Hummingbird karst told the senior author that Five Blues Lake had not existed in the 1950s, but had appeared after Hurricane Hattie in 1961. Additionally, he claimed that the lake had varied in size throughout its history, had shrunk considerably in the early 1970s, and had assumed its full extent only by around 1980.

These claims were initially given little credence, and they cannot be tested. Cartographic evidence appears to refute them, in that the lake appears, apparently unchanged, on 1:50,000 topographic maps dated 1945, 1955, and 1962 (Directorate of Overseas Surveys, 1945, 1955, 1962). Similarly, the lake appears on various air photographs taken in 1939, 1962, and 1969. Nonetheless, the intervals between these dates are such that cycles of filling and draining may not have been captured, so that it remains possible that dramatic fluctuations are not unusual and that there have been several episodes of filling and draining in historic times. The exposure of tree trunks in the lake bed by the rapid drainage is also suggestive of former variations in lake depths, as these trees must have become established when lake levels were lower.

Regardless of the recent history of Five Blues Lake, the lesson of the 2006 episode is that karst landscapes, and particularly hydrologic features such as lakes, rivers, waterfalls, swallets, and springs, are inherently dynamic over even very short periods of time. Their management and promotion within protected areas needs to take this into account, emphasizing variability and change, and avoiding a focus on conditions that may not prevail at any given time. Appropriate management strategies, then, should acknowledge the temporal variability of the hydrologic regime and prepare visitors for an experience falling within a wide spectrum of hydrologic conditions. This has the advantages of presenting a realistic scientific assessment of karst phenomena, buffering against potential visitor disappointment and, at the same time, adding to the karst mystique.

This approach has broad parallels at other karst sites where distinct temporal variations, although at differing scales, are in effect, such as in breathing caves or those exhibiting seasonal airflow reversals. Littoral karst that is subject to tidal inundation presents a further analogy, as does the timing of geysers such as Old Faithful in Yellowstone National Park (Azzalini and Bowman, 1990). More generally, all temporal changes relevant to a given protected karst area, such as climate changes, sealevel fluctuations, geomorphic development, or human vegetation modification, might usefully be incorporated into interpretive literature or websites during the establishment and development of the site.

In the case of Five Blues Lake, the story of the lake's dramatic drainage and refilling provides a considerable incentive for potential future visitors, who will now come to the park with realistic expectations and a sounder appreciation of the lake's hydrology. Visitor numbers may never be substantial, but they may now be expected to return to pre-drainage levels and even increase as a result of the lake's new-found notoriety, representing a significant contribution to park upkeep and the restricted local economy. A similar approach might be useful at the nearby Blue Hole, which is a far more popular tourism venue and where some visitors are disappointed during flood stages when the water is turbid and not the expected color. Management there might also prepare for the possibility of rapid drainage or even hydrologic abandonment of the Blue Hole, which is less deep and at a higher elevation than Five Blues Lake, so that such an event would not necessarily have an immediate adverse impact on tourism revenues.

\section{ACKNOWLEDGEMENTS}

We are grateful to Dr. Jan Meerman, Director of Belize Tropical Forest Studies, for permission to use the images reproduced here as Figures 3 and 5. Research in Belize by Mick Day has been financed in part by the Center for Latin American and Caribbean Studies at UW-Milwaukee and facilitated by the Lower Dover Field Station, Belize. We are grateful to past and present residents of Santa Martha/ St. Margaret's village, particularly Lee Wengrzyn, the former village chairman, and Mario Perez, current president of the Association of Friends of Five Blues Lake, for their cooperation. The American Geographical Society Library, UW-Milwaukee provided access to the 1:50,000 topographic maps, and the Lands and Surveys Department of the Government of Belize made accessible the air photographs. The Belize National Meteorological Service kindly provided the June and July 2006 rainfall data.

\section{REFERENCES}

Azzalini, A., and Bowman, A.W., 1990, A look at some data on the Old Faithful geyser: Journal of the Royal Statistical Society: Series C (Applied Statistics), v. 39, no. 3, p. 357-365.

Belize Audubon Society, 2010a, Richard batters Guanacaste and St. Herman's Blue Hole national parks: BAS News, v. 3, no. 9, 1 p.

Belize Audubon Society, 2010b, BAS Managed Protected Areas. http://www.belizeaudubon.org/protected_areas/protected-areas.html, [accessed October 3, 2010]. 
Beddows, P., 2004, Yucatán phreas, Mexico, in Gunn, J., ed., Encyclopedia of Caves and Karst Science: London, Fitzroy Dearborn, p. 786-788.

Belize National Meteorological Service, 2011a, The climate of Belize. http://www.hydromet.gov.bz/climate-summary.htm, [accessed January 18,2011$]$.

Belize National Meteorological Service, 2011b, Daily rainfall at Hummingbird Hershey, June and July 2006. Climatology Section, BNMS, unpublished data.

Bonacci, O., 2004a, Poljes, in Gunn, J., ed., Encyclopedia of Caves and Karst Science: London, Fitzroy Dearborn, p. 599-600.

Bonacci, O., 2004b, Ponors, in Gunn, J., ed., Encyclopedia of Caves and Karst Science: London, Fitzroy Dearborn, p. 600-601.

Bundschuh, J., Birkle, P., Finch, R.C., Day, M.J., Romero, J., Paniagua, S., Alvarado, G.E., Bhattacharya, P., Tippmann, K., and Chaves, D., 2007, Geology-related tourism for sustainable development, in Bundschuh, J., and Alvarado, G.E., eds., Central America: Geology, Resources, Hazards: London, Taylor \& Francis, v. 2, p. 1015-1098.

Community Conservation Consultants, 1999, Five Blues National Park: CCC Update, v. 10, no. 1, http://www.communityconservation. org/newsletters/Spring-Summer $\% 201999 \% 20$ Newsletter.htm, [accessed November 5, 2010].

Day, M.J., 1986, Karst and landuse in central Belize: Communications, $9^{\circ}$ Congreso Internacional de Espeleología, España 1986, v. 1, p. 221-223.

Day, M.J., 1987a, Landuse change in the Hummingbird karst - An introduction, in Landuse Change in the Hummingbird Karst: Department of Geography, University of Wisconsin-Milwaukee, Occasional Paper 1, p. 6-9.

Day, M.J., ed., 1987b, Environment and Resources in the Hummingbird Karst of Central Belize: Department of Geography, University of Wisconsin-Milwaukee, Occasional Paper 2, $166 \mathrm{p}$.

Day, M.J., 1987c, Slope form, erosion, and hydrology in some Belizean karst depressions: Earth Surface Processes and Landforms, v. 12, no. 5, p. 497-505, doi:10.1002/esp.3290120507.

Day, M.J., 1991, Resource use in rural tropical karstlands: the Hummingbird Karst, Belize, in Sauro, U., Bondesan, A., and Meneghel, M., eds., Proceedings of the International Conference on Environmental Changes in Karst Areas: Padova, Italy, University of Padova, Quaderni del Dipartimento de Geografia 13, p. 31-38.

Day, M.J., 1992, Geomorphology and hydrology of the Blue Hole, Caves Branch: Belizean Studies, v. 20, no. 3, p. 3-10.

Day, M.J., 1993, Resource use in the tropical karstlands of central Belize: Environmental Geology, v. 21, no. 3, p. 122-128, doi:10.1007/ BF00775295.

Day, M.J., 1996, Conservation of karst in Belize: Journal of Cave and Karst Studies, v. 58, no. 2, p. 139-144.

Day, M.J., 2003a, Faunal associations with karst landscapes: a preliminary assessment of bird observations in Belize: Cave and Karst Science, v. 30, no. 3, p. 101-106.

Day, M.J., 2003b, Some observations on karst landscape ecology and conservation in Belize: Journal of Belizean Affairs, v. 5, no. 1, p. $31-45$.

Day, M.J., 2004, Cenote, in Goudie, A.S., ed., Encyclopedia of Geomorphology: London, Routledge, p. 132-133.

Day, M.J., 2005, Salvadoran lime kiln establishment in the Hummingbird karst, Belize, 1979-1988: Caribbean Geography, v. 14, no. 2, p. $133-144$.

Day, M.J., 2007, Natural and anthropogenic hazards in the karst of Jamaica, in Parise, M., and Gunn, J., eds., Natural and Anthropogenic Hazards in Karst Areas: Recognition, Analysis and Mitigation: Geological Society Special Publication 279, London, The Geological Society, p. 173-184, doi:10.1144/ SP279.14.

Day, M.J., 2011, Protection of karst landscapes in the developing world: lessons from Central America, the Caribbean and Southeast Asia, in Van Beynen, P.E., ed., Karst Management: Rotterdam, Springer, p. $439-458$

Day, M.J., and Goudie, A.S., 1978, Why the Devil's Punchbowl dries up: The Geographical Magazine, v. 50, no. 6, p. 381-385.

Day, M.J., Gaertner, P., and Neal, M.K., 1987, A dye trace at the Blue Hole in Central Belize: The Wisconsin Speleologist, v. 20, no. 2, p. $1-12$.
Day, M.J., and Rosen, C.J., 1989, Human impact on the Hummingbird Karst of central Belize, in Gillieson, D.S., and Smith, D.I., eds., Resource Management in Limestone Landscapes: International Perspectives: Proceedings of the International Geographical Union Study Group Man's Impact on Karst, Sydney, 15-21 August 1988: Canberra, Australian Defence Force Academy, p. 201-214.

Directorate of Overseas Surveys, 1945, British Honduras 1:50,000 Topographic Series, Sheet 17, Provisional Edition.

Directorate of Overseas Surveys, 1955, British Honduras 1:50,000 Topographic Series, Sheet 17, 1st ed.

Directorate of Overseas Surveys, 1962, British Honduras 1:50,000 Topographic Series, Sheet 17, 2nd ed.

Directorate of Overseas Surveys, 1973, Belize 1:50,000 Topographic Series, Sheet $25,3 \mathrm{rd}$ ed.

Drew, D., and Hotzl, H., 1999, Karst Hydrogeology and Human Activities: Impacts, Consequences and Implications: Rotterdam, AA Balkema (IAH International Contributions to Hydrogeology), $322 \mathrm{p}$.

Escott, L., and Day, M.J., 2005, The Cayo West Special Development Area, Belize: towards sustainable land use planning?: Caribbean Geography, v. 14 , no. 1 , p. 55-72.

Ford, D.C., and Williams, P.W., 2007, Karst Hydrogeology and Geomorphology: Chichester, UK, Wiley, 562 p.

Horwich, R.H., and Lyon, J., 1999, Rural ecotourism as a conservation tool, in Singh, T.V., and Singh, S., eds., Tourism Development in Critical Environments: New York, Cognizant Communication Corporation, p. 102-119.

Kindinger, J.L., Davis, J.B., and Flocks, J.G., 1999, Geology and evolution of lakes in north-central Florida: Environmental Geology, v. 38, no. 4, p. 301-321, doi:10.1007/s002540050428.

Kovačič, G., and Ravbar, N., 2010, Extreme hydrological events in karst areas of Slovenia, the case of the Unica River basin: Geodinamica Acta, v. 23, no. 1-3, p. 89-100, doi:10.3166/ga.23.89-100.

Kueny, J.A., and Day, M.J., 1998, An assessment of protected karst landscapes in the Caribbean: Caribbean Geography, v. 9, no. 2, p. $87-100$.

Kueny, J.A., and Day, M.J., 2002, Designation of protected karstlands in Central America: a regional assessment: Journal of Cave and Karst Studies, v. 64 , no. 3, p. $165-174$.

Meerman, J., 2001, Report on a Short Assessment of the Shore Vegetation of Five Blues Lake National Park, http://biologicaldiversity.info/Downloads/eleocharis_report.pdf, [accessed November $5,2010]$.

Meerman, J., 2007, Five Blues Lake National Park: The Collapse (and Revival) of the Five Blues Lake Karstic Lake, Cayo District, Belize, http://biological-diversity.info/fiveblues.htm, [accessed December 3, 2010].

Miller, T.E., 1977, Karst of the Caves Branch, Belize: Proceedings of the 7th International Speleological Congress Sheffield, England, September $1977,314 \mathrm{p}$.

Miller, T.E., 1981, Hydrochemistry, hydrology, and morphology of the Caves Branch karst, Belize [PhD Thesis]: Hamilton, Ontario, McMaster University, $280 \mathrm{p}$.

Miller, T.E., 1983, Hydrology and hydrochemistry of the Caves Branch karst, Belize: Journal of Hydrology, v. 61, p. 83-88, doi:10.1016/ 0022-1694(83)90236-6.

Miller, T.E., 1996, Geologic and hydrologic controls on karst and cave development in Belize: Journal of Cave and Karst Studies, v. 58, no. 2, p. 100-120.

Miller, T.E., 2006, Integration of a large tropical cave network in brecciated limestone: Caves Branch, Belize, in Harmon, R.S., and Wicks, C.M., eds., Perspectives on Karst Geomorphology, Hydrology, and Geochemistry: A tribute Volume to Derek C. Ford and William B. White: Geological Society of America Special Paper, 404, p. $91-103$.

Naughton, O., Johnston, P., and Gill, L., 2010, The hydrology of turloughs as groundwater dependent terrestrial ecosystems, in Bonacci, O., ed., Sustainability of the Karst Environment - Dinaric Karst and other Karst Regions: Paris, UNESCO, IHP-VII Series on Groundwater no. 2, p. 147-154.

Petrič, M., and Kogovšek, J., 2005, Hydrogeological characteristics of the area of intermittent lakes of Pivka: Acta Carsologica, v. 34, no. 3, p. 599-618. 
Five Blues Lake National Park, Belize: a Cautionary management tale

Waltham, T., Bell, F., and Culshaw, M., 2005, Sinkholes and Subsidence: Karst and Cavernous Rocks in Engineering and Construction: Chichester, UK, Springer-Praxis, $382 \mathrm{p}$.

Warner, M., 1996, Strategic development planning at the community level: a modification to participatory planning: Community Development Journal, v. 31, no. 4, p. 330-342, doi:10.1093/cdj/31.4.330.

Watson, J., Hamilton-Smith, E., Gillieson, D., and Kiernan, K., eds., 1997, Guidelines for Cave and Karst Protection: Gland, Switzerland, IUCN World Commission on Protected Areas, 63 p.
White, L.E., 1994, Development options for a rural community in Belize alternative development and operational research: International Transactions in Operational Research, v. 1, no. 4, p. 453-462, doi:10.1111/ j.1475-3995.1994.00322.x.

Young, C., and Horwich, A., 2007, History of Protected Area Designation, Co-management and Community Participation in Belize, in Balboni, B., and Palacio, J., eds., Taking Stock: Belize at 25 years of Independence, volume 1: Benque Viejo del Carman, Belize, Cubola, p. 123-145. 